\title{
Supplementation of Curcuma longa hydrolate improves immunomodulatory response in Nile tilapia reared in a recirculation aquaculture system
}

\author{
[Suplementação de extrato aquoso de Curcuma longa aprimorando a resposta imunomoduladora \\ em tilápias cultivadas em sistema de recirculação em aquicultura] \\ M.O. Pereira' ${ }^{1}$, A.V. Moraes ${ }^{2,3}$, J.C.B. Rodhermel ${ }^{4}$, J.D. Hess ${ }^{4}$, L. Alves ${ }^{5}$, \\ A. Chaaban ${ }^{5}$, A. Jatobát ${ }^{*}$ \\ ${ }^{1}$ Médica veterinária - Taboado, MS \\ ${ }^{2}$ Médica veterinária - Barra Velha, SC \\ ${ }^{3}$ Aluna de pós-graduação - Instituto Federal Catarinense - Araquari, SC \\ ${ }^{4}$ Laboratório de Aquicultura - Instituto Federal Catarinense - Araquari, SC \\ ${ }^{5}$ Instituto Federal Catarinense - Araquari, SC
}

\begin{abstract}
The objective of this study was to evaluate the effects of dietary supplementation with different doses of Curcuma longa hydrolate on the hematological, immunological and zootechnical parameters of Nile tilapia cultivated in a recirculation system (RAS). Nile tilapia (Oreochromis niloticus) were used, distributed in 16 polyethylene boxes, divided into four treatments: $0.0 \% ; 2.5 \% ; 7.5 \%$ and $10.0 \%$ of Curcuma longa hydrolate, in quadruplicate. After 45 days of treatment, four fish per experimental unit were anesthetized to remove blood aliquot for hematological and immunological analyzes and dissect the liver to evaluate the hepatosomatic index and final biometry. In the haematological analysis, the fish fed with $2.5 \%$ had a higher number of leukocytes, monocytes and lymphocytes than control, while the doses of $7.5 \%$ and $10.0 \%$ did not differ. Antimicrobial activity showed a significant decrease as the dose of $C$. longa hydrolate increased. The other hematological, immunological, hepatosomatic index and zootechnical data did not differ between treatments. Thus, supplementation of the hydrolate of Curcuma longa at a dosage of $2.5 \%$, improved and maintained blood-immune homeostasis parameters in these animals, being suggested for further studies.
\end{abstract}

Keywords: alternative therapeutics, phytotherapeutics, curcumin, immunomodulatory

\section{RESUMO}

O objetivo deste estudo foi avaliar os efeitos da suplementação dietética com diferentes doses de hidrolato de Curcuma longa nos parâmetros hematológicos, imunológicos e zootécnicos da tilápia-do-nilo cultivada em sistema de recirculação. Utilizou-se tilápia- do-nilo (Oreochromis niloticus), distribuída em 16 caixas de polietileno, divididas em quatro tratamentos: $0,0 \% ; 2,5 \% 7,5 \%$ e 10,0\% de hidrolato de Curcuma longa, em quadruplicata. Após 45 dias de tratamento, quatro peixes por unidade experimental foram anestesiados para remover uma alíquota sanguínea para análises hematológicas e imunológicas, e removeu-se o fígado para avaliar o indice hepatossomático e a biometria final. Na análise hematológica, os peixes alimentados com 2,5\% apresentaram maior número de leucócitos, monócitos e linfócitos que no controle, enquanto as doses de 7,5\% e 10,0\% não diferiram. Por outro lado, a atividade antimicrobiana apresentou uma redução significativa à medida que a dose de hidrolato de C. longa aumentou. Os demais dados hematológicos, imunológicos, hepatossomáticos e zootécnicos não diferiram entre os tratamentos. Assim, a suplementação do hidrolato de Curcuma longa, na dose de 2,5\%, melhorou os parâmetros hematoimunológicos e manteve a homeostase nesses animais, sendo sugerida para novos estudos.

Palavras-chave: terapia alternativa, fitoterápicos, curcumina, imunomodulador

Recebido em 20 de dezembro de 2019

Aceito em 10 de abril de 2020

*Autor para correspondência (corresponding author)

E-mail: jatobaadolfo@gmail.com 


\section{INTRODUCTION}

Since fish production from fisheries cannot meet current demand, aquafarming has spread worldwide to supply fish for human consumption. Between 2007 and 2016, fish farming increased by $60 \%$, representing an increase of 50 million $\mathrm{t} /$ year over the same period and Nile tilapia has been a great contributor to this increase (Indicators..., 2017).

Nile tilapia (Oreochromis niloticus) is the most produced species in Brazil, accounting for $51.7 \%$ of national fish farming, with 357,639 tons in 2017, making Brazil the fourth largest tilapia producer in the world (Anuário..., 2018). This statistic is supported by the fact that Nile tilapia is omnivorous, exhibits rapid growth, easily adapts to artificial food and intensive production systems, and is well accepted by consumers (Vicente et al., 2014).

However, intensification of production systems in the absence of good management practices can lead to the emergence of diseases (Jatobá et al., 2011; Lacerda et al., 2013). To treat disease outbreaks, chemotherapeutic substances are frequently used; however, these drugs can cause residual effects, in addition to favoring the selection of pathogenic microorganisms in the environment (Cabello et al., 2013).

Thus, it behooves researchers to identify alternative treatments to the commonly used antibiotics, e.g., phytotherapeutics. Such substitutes can be administered in the form of extracts, essential oils, or aqueous extract, the product of hydrolysis. Such alternative therapeutics exhibit antimicrobial (Meepagala and Schrader, 2018), antiparasitic (Valentim et al., 2018) and immunomodulatory (Song et al., 2018) activities in fish.

In particular, hydrolates, also known as herbal distillates, constitute the aqueous fraction that contains the emulsified essential oil; yet, it is generally discarded (Teske and Trentini, 1997). Nevertheless, many studies have reported on the efficiency of this by-product. For example, Mello et al. (2015) observed the efficacy of $62.82 \%$ of Rosemary officinalis hydrolate as antiparasitic, while the essential oil obtained $40.78 \%$, highlighting the acaricidal activities of this aqueous extract, which, up to time of that study, had been ignored. Curcuma longa, known as the turmeric of the world, is a spice used in cuisine around the world, but it is also used to treat many diseases and is one of the main components of curcumin.

Some studies have reported mechanisms of action of this plant on fish, such as antimicrobial activity against pathogenic bacteria (Singh et al., 2017), higher stress tolerance during yellowtail lambari transport (Ferreira et al., 2017b) and better growth performance in Nile tilapia (Mahmoud et al., 2017). Therefore, this study aimed to evaluate the effects of dietary supplementation of Curcuma longa hydrolate, with different doses, on hematoimmune parameters and growth performance of Nile tilapia reared in a recirculation aquaculture system (RAS).

\section{MATERIALS AND METHODS}

This study was carried out in the Laboratório de Aquicultura (Laq) do Instituto Federal Catarinense (IFC), Campus Araquari, and it was approved by the National Council for the Control of Animal Experimentation (CONCEA) under protocol number 157/2016.

The Curcuma longa used in this work were grown in the Medicinal Plant Lab of the IFC, located at $26^{\circ} 23$ ' 33, 6691 "S and $48^{\circ} 44^{\prime}$ '18.3336" W, 10.6 $\mathrm{m}$ above the sea level in the city of Araquari, Santa Catarina, southern Brazil. The cultivation was performed in an agroecological system without addition of chemicals. A sample of the botanical species was deposited in the Herbarium of the Botanical Museum, located in the Botanical Garden of Curitiba, PR, under number 358970.

After nine months of cultivation, C.longa was harvested, sanitized, separated into $100 \mathrm{~g}$ samples to be crushed with the aid of a blender. The extraction was achieved by hydrodistillation (Venskutonis, 1997) using the Clevenger apparatus adapted to a $2000 \mathrm{~mL}$ flask wherein the sample was placed together with $1000 \mathrm{~mL}$ of distilled water according Coradi et al. (2018).

The extraction time was $90 \mathrm{~min}$, starting from the time of boiling. After the hydrolate (mixture of oil and water) was obtained, separation of the essential oil was initiated using the organic solvent, pentane $(3 \times 50 \mathrm{~mL})$ in a separatory funnel. After a few minutes of resting, the solution was 
filtered and concentrated on a rotary evaporator at $40^{\circ} \mathrm{C}$ until the solvent volume significantly reduced. Diets were supplemented with C. longa hydrolate in four different concentrations. Distilled water was used to maintain the same moisture level of the diets, according to Table 1.

Table 1. Experimental diets with different levels of Curcuma longa hydrolate

\begin{tabular}{llll}
\multicolumn{1}{c}{ Treatment } & Hydrolate $(\%)$ & Distilled water $(\%)$ & Moisture $(\%)$ \\
\hline $0.0 \%$ (Control) & 0.0 & 10.0 & 10.0 \\
$2.5 \%$ & 2.5 & 7.5 & 10.0 \\
$7.5 \%$ & 7.5 & 2.5 & 10.0 \\
$10.0 \%$ & 10.0 & 0.0 & 10.0 \\
\hline
\end{tabular}

The experiment was performed on 160 Nile tilapia (Oreochromis niloticus) with a mean weight of $7.45 \pm 0.38 \mathrm{~g}$, distributed randomly in 16 polyethylene tanks $(800 \mathrm{~L})$ equipped with a constant recirculation system and divided into five treatments (Table 1) in quadruplicate and turmeric (Curcuma longa) seedlings, both from the IFC Araquari campus. Fish were fed three times a day with $3 \%$ of their biomass, and biometrics was performed weekly for food management. ile $\mathrm{pH}$ and ammonia were measured weekly. Dissolved oxygen and temperature (YSI55; YSI Incorporated, Yellow Springs, OH, USA) were performed twice a day, while $\mathrm{pH}$, ammonia (total ammonia nitrogen - TAN), nitrite-N and nitrate$\mathrm{N}$ were also monitored twice a week according to APHA (Standard..., 2005).

After 45 days of rearing and a $24 \mathrm{~h}$ period of starvation, all animals per experimental unit were anesthetized with Eugenol (50mg. $\left.\mathrm{L}^{-1}\right)$ and sacrificed by cerebral concussion. Three were used for microbiological assays of the digestive tract, and the others were used for hematological and immunological assays, five each. Final biometry was performed and hepatosomatic index (liver weight / body weight * 100), specific growth rate (final weight - initial weight / initial weight) and survival were analyzed.

For hematological analysis, approximately $0.5 \mathrm{~mL}$ of blood was drawn from the caudal vein of each fish for the preparation of blood smears, in duplicate, and the following hematological analyses were performed: determination of hematocrit by the standard microhematocrit method; glucose (G-TECH free®, AccumedGlicomed, Brazil); total hemocyte count by Neubauer hemocytometer and hemoglobin concentration. Hematimetric absolute rates of mean corpuscular volume (MCV), mean corpuscular hemoglobin $(\mathrm{MCH})$ and mean corpuscular hemoglobin concentration (MCHC) were also obtained. Blood smear slides were stained with May-Grünwald-Giemsa (MGG) stain (Ranzani-Paiva et al., 2013) for total and differential leukocyte count (Jatobá et al., 2011).

From the same fish used in the hematological evaluation, total blood was also collected without anticoagulant to obtain the blood serum used for immunological analyses. Lysozyme activity was measured using spectrophotometry according to Ellis (1990), with lyophilized chicken egg white as standard. For concentration of total plasma protein, a commercial kit (Lab Test ${ }^{\circledR}$ ) was used, with bovine albumin for the standard curve. Total immunoglobulin concentration was assessed according to the method of Amar et al. (2000). Agglutination titer was performed with inactivated Aeromonas hydrophila (CPQBA 22808 DRM), and plasma antimicrobial activity was performed against two bacteria: A. hydrophila (CPQBA 228-08 DRM) and Enterococcus durans (ATCC 19492), according by Silva et al. (2009).

Data were submitted to the Kolmogorov-Smirnov test to determine if data distribution was within the normality curve and Levene's test to verify homoscedasticity. Data obtained that met the prerequisites of normality and homoscedasticity, one-way ANOVA and significant differences among treatments were analyzed using the Student-Newman-Keuls (SNK) test. The hepatosomatic index was submitted to secondorder polynomial regression. All tests were conducted at a 5\% level of significance (Zar, 2010).

\section{RESULTS AND DISCUSSION}

The mean values and variations recorded in water quality parameters were considered adequate for rearing Nile tilapia (Kubitza, 2011) and did not differ among treatments (Table 2). Equality among water quality variables ensures that the 
observed changes were related to the diets, ingredients, or supplements tested. For total and differential leukocyte count, fish fed a diet supplemented with $2.5 \%$ C. longa hydrolate showed a higher number of lymphocytes and neutrophils in relation to control. The number of basophils, eosinophils, thrombocytes and circulating erythrocytes did not differ among treatments, as well hematocrit and blood glucose level (Table 3). Analysis of blood parameters allows for the identification and control of stress, as well as disease and treatment options, in order to ensure the health of fish and sanitary condition of the rearing environment, further standardizing rearing conditions, if necessary (Tavares-Dias $e t$ al., 2009).

Table 2. Water quality parameters of tanks with Nile tilapia fed with different doses of Curcuma longa hydrolate for 45 days, in water recirculation system

\begin{tabular}{lllll}
\multicolumn{1}{c}{ Parameters } & \multicolumn{4}{c}{ Treatments } \\
& \multicolumn{1}{c}{$0.0 \%$} & \multicolumn{1}{c}{$2.5 \%$} & $7.5 \%$ & $10.0 \%$ \\
\hline Dissolved oxygen $\left(\mathrm{mg} . \mathrm{L}^{-1}\right)$ & $5.36 \pm 1.52^{\mathrm{a}}$ & $5.12 \pm 1.12^{\mathrm{a}}$ & $5.26 \pm 1.21^{\mathrm{a}}$ & $5.31 \pm 1.72^{\mathrm{a}}$ \\
Temperature $\left({ }^{\circ} \mathrm{C}\right)$ & $22.21 \pm 2.37^{\mathrm{a}}$ & $22.25 \pm 2.21^{\mathrm{a}}$ & $22.45 \pm 3.01^{\mathrm{a}}$ & $22.78 \pm 1.34^{\mathrm{a}}$ \\
$\mathrm{pH}$ & $7.53 \pm 0.31^{\mathrm{a}}$ & $7.51 \pm 0.22^{\mathrm{a}}$ & $7.30 \pm 0.41^{\mathrm{a}}$ & $7.44 \pm 0.21^{\mathrm{a}}$ \\
Total ammonia $\left(\mathrm{mg} . \mathrm{L}^{-1}\right)$ & $0.11 \pm 0.05^{\mathrm{a}}$ & $0.12 \pm 0.06^{\mathrm{a}}$ & $0.11 \pm 0.02^{\mathrm{a}}$ & $0.16 \pm 0.05^{\mathrm{a}}$ \\
Nitrite $\left(\mathrm{mg} . \mathrm{L}^{-1}\right)$ & $0.05 \pm 0.02^{\mathrm{a}}$ & $0.05 \pm 0.02^{\mathrm{a}}$ & $0.05 \pm 0.01^{\mathrm{a}}$ & $0.05 \pm 0.03^{\mathrm{a}}$ \\
\hline
\end{tabular}

* Different letters indicate significant differences $(\mathrm{P}<0.05)$ between treatments in ANOVA and SNK test.

In this study, no difference on erythrocytes, hematocrit or glucose were found among treatments. The oscillation in erythrocyte, hematocrit and glucose values of fish is commonly related to stressors, such as contact with pathogens, poor water quality in the growing environment or transport (Neves et al., 2018). This demonstrates that the conditions of the experiment were within those required by the species and that supplementation with $C$. longa hydrolate, irrespective of dosage, did not interfere with the homeostasis of these animals.

Neutrophils, basophils, eosinophils and monocytes mediate activities of the innate immune system, which mounts host defense against infection by invading organisms (Thrall, 2014). Because they may have an immunomodulatory effect on these cells, phytotherapeutics have been shown to activate defense mechanisms earlier than control treatments, favoring the health of animals (Chakraborty and Hancz, 2011).

Fish fed the $2.5 \%$ dose of $C$. longa hydrolate presented higher total leukocytes $(\mathrm{P}<0.05)$ than the control treatment. This result corroborates the findings of Sodamola et al. (2016) who fed African catfish the powder of $C$. longa for 20 days and reported an increase in leukocytes and thrombocytes, indicating improved immunomodulation in the animals. Basophils, eosinophils and circulating thrombocytes did not differ among treatments. These cells are called to action during inflammation to defend against parasites, allergens, and hemostasis, respectively (Thrall, 2014).

Table 3. Hematological variables of Nile tilapia (Oreochromis niloticus) fed diets supplemented with different doses of Curcuma longa hydrolate

\begin{tabular}{|c|c|c|c|c|}
\hline \multirow{2}{*}{ Parameters } & \multicolumn{4}{|c|}{ Treatments } \\
\hline & $0 \%$ & $2.5 \%$ & $7.5 \%$ & $10.0 \%$ \\
\hline Leukocyte (x 10 $\left.{ }^{4} . \mu \mathrm{L}^{-1}\right)$ & $12.15 \pm 2.90^{\mathrm{a}}$ & $27.49 \pm 5.60^{\mathrm{b}}$ & $23.70 \pm 6.00^{\mathrm{ab}}$ & $23.04 \pm 7.40^{\mathrm{ab}}$ \\
\hline Thrombocyte (x $\left.10^{4} . \mu \mathrm{L}^{-1}\right)$ & $15.55 \pm 4.50^{\mathrm{a}}$ & $21.39 \pm 5.10^{\mathrm{a}}$ & $18.70 \pm 5.20^{\mathrm{a}}$ & $23.52 \pm 6.80^{\mathrm{a}}$ \\
\hline Basophil $\left(\mathrm{x} 10^{3} \cdot \mu \mathrm{L}^{-1}\right)$ & $0.00 \pm 0.00^{\mathrm{a}}$ & $0.00 \pm 0.00^{\mathrm{a}}$ & $0.00 \pm 0.00^{\mathrm{a}}$ & $0.46 \pm 0.40^{\mathrm{a}}$ \\
\hline Monocyte $\left(x 10^{3} \cdot \mu \mathrm{L}^{-1}\right)$ & $15.30 \pm 2.30^{\mathrm{a}}$ & $25.50 \pm 4.50^{\mathrm{b}}$ & $14.40 \pm 3.70^{\mathrm{a}}$ & $18.20 \pm 7.30^{\mathrm{ab}}$ \\
\hline Lymphocyte $\left(\mathrm{x} 10^{3} \cdot \mu \mathrm{L}^{-1}\right)$ & $205.00 \pm 7.00^{\mathrm{a}}$ & $243.00 \pm 21.00^{\mathrm{b}}$ & $220.00 \pm 13.10^{\mathrm{ab}}$ & $207.00 \pm 7.79^{\mathrm{ab}}$ \\
\hline Neutrophil $\left(\mathrm{x} 10^{3} \cdot \mu \mathrm{L}^{-1}\right)$ & $1.28 \pm 0.90^{\mathrm{a}}$ & $4.59 \pm 2.20^{\mathrm{b}}$ & $8.79 \pm 3.30^{\mathrm{b}}$ & $3.12 \pm 1.50^{\mathrm{ab}}$ \\
\hline Eosinophil $\left(\mathrm{x} 10^{3} \cdot \mu \mathrm{L}^{-1}\right)$ & $0.00 \pm 0.00^{\mathrm{a}}$ & $0.65 \pm 0.40^{\mathrm{a}}$ & $0.00 \pm 0.00^{\mathrm{a}}$ & $0.00 \pm 0.00^{\mathrm{a}}$ \\
\hline Erythrocytes $\left(10^{6} \mu \mathrm{L}^{-1}\right)$ & $2.40 \pm 0.60^{\mathrm{a}}$ & $3.80 \pm 0.70^{\mathrm{a}}$ & $3.48 \pm 0.70^{\mathrm{a}}$ & $3.10 \pm 0.70^{\mathrm{a}}$ \\
\hline Hematocrit $(\%)$ & $29.05 \pm 2.40^{\mathrm{a}}$ & $29.21 \pm 2.60^{\mathrm{a}}$ & $30.00 \pm 3.00^{\mathrm{a}}$ & $30.50 \pm 2.00^{\mathrm{a}}$ \\
\hline
\end{tabular}

* Different letters indicate significant differences $(\mathrm{P}<0.05)$ between treatments in ANOVA and SNK test. 
Neutrophils are the first leukocytes to be recruited when foreign material enters the body. They are responsible for eliminating or limiting pathogenic growth through the action of myeloperoxidase and oxidative burst enzymes, allowing time for adaptive immune responses to progress (Zachary et al., 2018). In the present work, an increase in the amount of these defense cells in the blood of fish was in line with the result of Brum et al. (2017), who also observed a significant increase of these cells in Nile tilapia supplemented with essential oils of basil (Ocimum gratissimum) and ginger (Zingiber officinale) for 45 days, indicating an improvement in the immune response of fish after experimental infection with Streptococcus agalactiae.

During tissue diapedesis, monocytes are referred to as macrophages and are responsible for the processing and presenting antigens to lymphocytes, linking the innate and adaptive immune system (Zachary et al., 2018). In this research, the $2.5 \%$ treatment resulted in a significant increase of monocytes and lymphocytes $(\mathrm{P}<0.05)$ in relation to control. A greater presence of circulating monocytes and lymphocytes associated with improved immunomodulatory properties was also observed in Labeo rohita fed a diet supplemented with $C$. longa (Sahu et al., 2008). C. longa hydrolate also stimulates the presence of these defense cells in the bloodstream, likely enhancing immune response.

Agglutination titer, total serum protein, immunoglobulin, agglutination titer, lysozyme and glucose (Table 4), showed no significant difference among treatments. On the other hand, antimicrobial activity showed a significant decrease as the dose of $C$. longa hydrolate increased. The decrease of antimicrobial blood serum capacity of fish fed diets supplemented with $C$. longa hydrolate was observed. This decrease may be associated with the activity of the bioactive substances of $C$. longa already described in the literature as possible antimicrobial agents (Zorofchian Moghadamtousi et al., 2014).

Table 4. Immunological variables of Nile tilapia (Oreochromis niloticus) fed diets supplemented with different doses of Curcuma longa hydrolate

\begin{tabular}{|c|c|c|c|c|}
\hline \multirow{2}{*}{ Parameters } & \multicolumn{4}{|c|}{ Treatments } \\
\hline & $0 \%$ & $2.5 \%$ & $7.5 \%$ & $10.0 \%$ \\
\hline Protein $\left(\mathrm{mg} . \mathrm{L}^{-1}\right)$ & $47.09 \pm 5.96^{\mathrm{a}}$ & $43.84 \pm 7.22^{\mathrm{a}}$ & $42.28 \pm 4.99^{\mathrm{a}}$ & $43.59 \pm 3.76^{\mathrm{a}}$ \\
\hline Immunoglobulin $\left(\mathrm{mg} \cdot \mathrm{L}^{-1}\right)$ & $20.17 \pm 5.49^{\mathrm{a}}$ & $17.38 \pm 5.16^{\mathrm{a}}$ & $17.71 \pm 7.68^{\mathrm{a}}$ & $18.72 \pm 6.25^{\mathrm{a}}$ \\
\hline Lysozyme (UI.mL $\left.{ }^{-1}\right)$ & $224.04 \pm 52.74^{\mathrm{a}}$ & $233.30 \pm 44.30$ & ${ }^{\mathrm{a}} 160.62 \pm 30.81^{\mathrm{a}}$ & $224.00 \pm 32.30^{\mathrm{a}}$ \\
\hline Antimicrobial Activity $\left(\log 2_{(x+1)}\right)$ & $1.58 \pm 0.00^{\mathrm{b}}$ & $1.58 \pm 0.00^{\mathrm{b}}$ & $1.19 \pm 0.79^{\mathrm{ab}}$ & $0.40 \pm 0.79^{\mathrm{a}}$ \\
\hline Agglutination titer $(\log 2)$ & $4.00 \pm 0.82^{\mathrm{a}}$ & $3.75 \pm 0.50^{\mathrm{a}}$ & $4.00 \pm 0.58^{\mathrm{a}}$ & $3.75 \pm 0.96^{\mathrm{a}}$ \\
\hline Glucose $\left(\mathrm{mg} \mathrm{dl}^{-1}\right)$ & $75.33 \pm 15.70^{\mathrm{a}}$ & $70.0 \pm 32.90^{\mathrm{a}}$ & $86.8 \pm 22.30^{\mathrm{a}}$ & $75.5 \pm 12.20^{\mathrm{a}}$ \\
\hline
\end{tabular}

*Different letters indicate significant differences $(\mathrm{P}<0.05)$ between treatments in ANOVA and SNK test.

Changes in serum protein concentrations are directly related to the homeostasis of animals, as they act in humoral defense and hemostasis (Mello et al., 2015). Thus, this similarity among treatments indicates that supplementation with the different doses of hydrolate did not affect serum osmotic balance of the animals and contributed to their survival.

Agglutination of pathogens is mediated mainly by immunoglobulins and proteins secreted by lymphocytes which form part of humoral immunity (Abbas et al., 2015). In this study, agglutination capacity did not vary among the treatments since no difference in the concentration of immunoglobulins was found. In contrast, Leya et al. (2017) reported a significant increase of serum protein and immunoglobulins after infection with Edwardsiella tarda_in Cirrhinus mrigala supplemented with $C$. longa powder in the diet for 45 days, attributing this to the enhancement of the humoral immune response.

Lysozyme is an important marker of the fish defense system, and it is part of the innate immune system. This enzyme has lytic function against bacteria and may be present in the mucus and serum of fish (Magnadóttir, 2006). In the present study, no difference in the amount of lysozyme was found among the treatments, a finding which stands in contrast to that of Abdel-Tawwab and Abbass (2017) who observed an increase of lysozyme in Cyprinus carpio against infection 
with Aeromonas hydrophila after feeding with $C$. longa powder for 10 weeks.

Survival was $100 \%$ in all treatments, while final weight, final length, specific growth rate, and hepatosomatic index did not differ among them (Table 5). On the other hand, Yusuf et al. (2017) reported that Nile tilapia fed $2 \mathrm{~g} \cdot \mathrm{kg}^{-1}$ of turmeric powder for three months experienced an increase in final weight and length, improving the animal's growth performance. The divergence of data on growth performance, as well as those related to immunity, may be related to the way $C$. longa was supplied in the diet. That is, while hydrolate, i.e., the by-product of essential oils extract, was used in some works, several other authors (Abdelrazek et al. 2017; Al-faragi and Hassan, 2017) have used
C. longa in powder form, the bioactive substances of which are generally found in higher concentrations.

Hepatosomatic index showed a reduction directly proportional to the dose increase of $C$. longa hydrolate (Figure 1). The HSI did not show a significant difference among the different doses of C. longa hydrolate, but in the polynomial regression analysis, a decrease in the values was seen since the hydrolate doses increased. These data agree with those of Ferreira et al. (2017a) who observed a lower number of capillaries, glycogen deposition and blood flow in Astyanax aff. bimaculatus supplemented for 60 days with high doses of C. longa.

Table 5. Growth performance of Nile tilapia fed with Curcuma longa hydrolate for 45 days and cultured in a recirculation system (RAS)

\begin{tabular}{lllll}
\multicolumn{1}{c}{ Parameters } & \multicolumn{4}{c}{ Treatments } \\
& \multicolumn{1}{c}{$0 \%$} & \multicolumn{1}{c}{$2.5 \%$} & \multicolumn{1}{c}{$7.5 \%$} & $10.0 \%$ \\
\hline Final weight $(\mathrm{g})$ & $102.10 \pm 18.40^{\mathrm{a}}$ & $104.03 \pm 9.60^{\mathrm{a}}$ & $100.40 \pm 14.40^{\mathrm{a}}$ & $94.22 \pm 10.90^{\mathrm{a}}$ \\
Final length $(\mathrm{cm})$ & $16.73 \pm 1.00^{\mathrm{a}}$ & $16.88 \pm 0.50^{\mathrm{a}}$ & $16.67 \pm 0.80^{\mathrm{a}}$ & $16.48 \pm 0.70^{\mathrm{a}}$ \\
Specific growth rate $\left(\%\right.$. day $\left.^{-1}\right)$ & $2.37 \pm 0.10^{\mathrm{a}}$ & $2.41 \pm 0.00^{\mathrm{a}}$ & $2.37 \pm 0.10^{\mathrm{a}}$ & $2.31 \pm 0.10^{\mathrm{a}}$ \\
Hepatosomatic index $(\%)$ & $3.32 \pm 0.40^{\mathrm{a}}$ & $2.95 \pm 0.30^{\mathrm{a}}$ & $2.77 \pm 0.40^{\mathrm{a}}$ & $2.51 \pm 0.20^{\mathrm{a}}$ \\
\hline
\end{tabular}

*Different letters indicate significant differences $(\mathrm{P}<0.05)$ between treatments in ANOVA and SNK test.

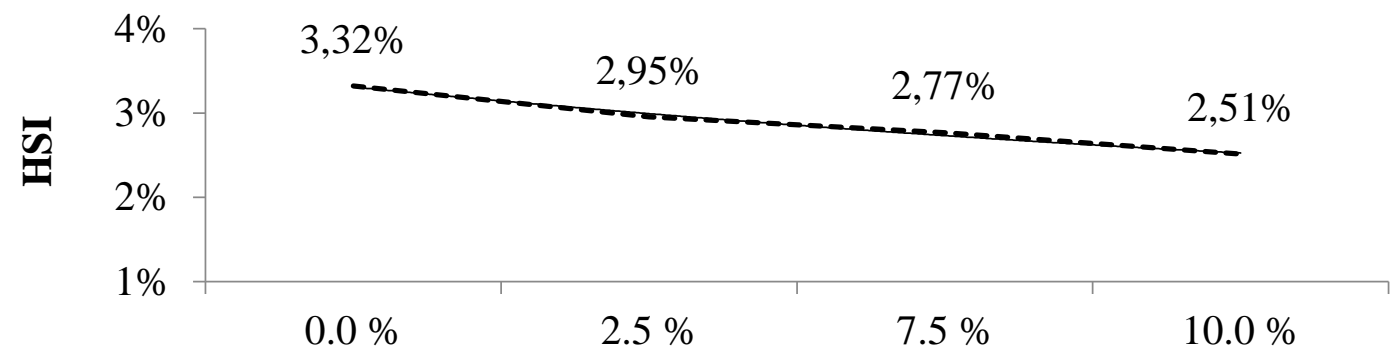

Figure 1. Second-order polynomial regression $\left(0,0003 x^{2}-0,004 x+0,0368 ; R^{2}=99,11\right)$ on effect of supplementation of different doses of Curcuma longa hydrolate on the hepatosomatic index (HSI) of Nile tilapia.

\section{CONCLUSION}

Curcuma longa hydrolate changes the hematological and immunological parameters of Nile tilapia (Oreochromis niloticus) fingerlings reared in RAS, keeping fish healthy and does not impair the growth performance. Among the evaluated doses, the inclusion of $2.5 \%$ of Curcuma longa in diet provided the best hematological alterations, increasing the number of circulating lymphocytes.

\section{ACKNOWLEDGMENTS}

The authors of this study acknowledge Conselho Nacional de Desenvolvimento Científico e Tecnológico (CNPq, process number 427632/2018-8) and Núcleo de Inovação tecnológica (NIT, edital 079/2016) for funding; GUABI for financing the diets used; and Luiz Sérgio Moreira for technical support. 


\section{REFERENCES}

ABBAS, A.K.; LITCHMAN, A.H.; PILLAI, S. Imunologia celular e molecular. Rio de Janeiro: Elsevier Brasil, 2015.

ABDEL-TAWWAB. M.; ABBASS, F.E Turmeric powder, Curcuma longa L., in common carp, Cyprinus carpio L., diets: growth performance, innate immunity, and challenge against pathogenic Aeromonas hydrophila infection. J. World Aquacult. Soc., v.48, p.303312, 2017.

AL-FARAGI, J.K.; HASSAN, M.A.H. Efficiency of dietary turmeric on growth performance, hematology and survival rate in common carp Cyprinus carpio Challenged with Flexibacter columnaris. Kufa J. Vet. Sci., v.8, p.130-140, 2017.

AMAR, E.C.; KIRON, V.; SATOH ,S.; OKAMOTO, N.; WATANABE, T. Effects of dietary $\beta$ carotene on the immune response of rainbow trout Oncorhynchus mykiss. Fish. Sci., v.66, p.1068-1075, 2000.

ANUÁRIO PeixeBR da piscicultura. São Paulo: Associação Brasileira de Piscicultura, 2018.

BRUM, A.; PEREIRA, S.A.; OWATARI, M.S. et al. Effect of dietary essential oils of clove basil and ginger on Nile tilapia (Oreochromis niloticus) following challenge with Streptococcus agalactiae. Aquaculture, v.468, p.235-243, 2017.

CABELLO, F.C.; GODFREY, H.P.; TOMOVA, A. et al. Antimicrobial use in aquaculture reexamined: its relevance to antimicrobial resistance and to animal and human health. Environ. Microbiol., v.15, p.1917-1942, 2013.

CHAKRABORTY, S.B.; HANCZ, C. Application of phytochemicals as immunostimulant, antipathogenic and antistress agents in finfish culture. Rev Aquacult., v.3, p.103-119, 2011.

CORADI, P.C.; MÜLLER, A.; SCHMIDT, D.A. et al. Electric conductivity test for quality assessment of aromatic and medicinal plants after drying. Drying Technol., v.36, p.545-556, 2018.

FERREIRA, P.D.M.F.; MARTINS, M.T.S.; CALDAS, D.W. et al. Curcuma longa as additive in the diet for Astyanax aff. Bimaculatus. Fish. Physiol. Biochem., v.43, p.691-702, 2017a.
FERREIRA, P.D.M.F.; ROCHA, J.S.; GOMES, J.R. et al. Curcuma longa supplementation in the diet of Astyanax aff. bimaculatus in preparation for transport. Aquacult. Res., v.48, p.4524-4532, $2017 b$.

INDICATORS - measuring up to the 2030. 2017. Rome: FAO, 2017. (Agenda for Sustainable Development.)

JATOBÁ, A.; NASCIMENTO VIEIRA, F.; BUGLIONE NETO, C.C. et al. Diet supplemented with probiotic for Nile tilapia in polyculture system with marine shrimp. Fish Physiol. Biochem., v.37, p.725-732, 2011.

KUBITZA F. Tilápia: tecnologia e planejamento na produção comercial. São Paulo: Acqua Supre Com Suprim Aquicult. 2011.

LACERDA, A.C.F.; YAMADA, F.H.; ANTONUCCI, A.M.; TAVARES-DIAS, M. Peixes introduzidos e seus parasitos. Brasília: Embrapa, 2013. 170p.

LEYA, T.; RAMAN, R.P.; SRIVASTAVA, P.P. et al. Effects of Curcumin Supplemented Diet on Growth and Non-Specific Immune Parameters of Cirrhinus mrigala against Edwardsiella tarda Infection. Int. J. Curr. Microbiol. App. Sci., v.6, p.1230-1243, 2017.

MAGNADÓTTIR, B. Innate immunity of fish (overview). Fish Shellfish Immun., v.20, p.137$151,2006$.

MAHMOUD, H.K.; AL-SAGHEER, A.A.; REDA, F.M.; MAHGOUB, S.A.; AYYAT, M.S. Dietary curcumin supplement influence on growth, immunity, antioxidant status, and resistance to Aeromonas hydrophila in Oreochromis niloticus. Aquaculture, v.475, p.1623, 2017.

MEEPAGALA, K.M.; SCHRADER, K.K. Antibacterial activity of constituents from mangosteen garcinia mangostana fruit pericarp against several channel catfish pathogens. $J$. Aquat. Anim. Health, v.30, p.179-184, 2018.

MELLO, V.; VILELA, F.; DAEMON, E.; PRATA, M.; AMARAL, M. Eficácia carrapaticida de formulações contendo óleo essencial e hidrolato de Rosmarinus officinalis. Biotecnol. Cienc., v.4, 2015. 
NEVES, M.S.; COUTO, M.V.S.; SOUSA, N.C. et al. Resposta hematológica do cascudo ornamental amazônico Peckoltia oligospila ao estresse de transporte. Arq. Bras. Med. Vet. Zootec., v.70, p.13-19, 2018.

RANZANI-PAIVA, M.J.T.; PÁDUA, .SB.; TAVARES-DIAS, M.; EGAMI, M.I. Métodos para análise hematológica em peixes. Paraná: Universidade Estadual de Maringá-EDUEM, 2013.

SAHU, S.; DAS, B.K.; MISHRA, B.K. et al. Effect of dietary Curcuma longa on enzymatic and immunological profiles of rohu, Labeo rohita (Ham.), infected with Aeromonas hydrophila. Aquacult .Res., v.39, p.1720-1730, 2008.

SINGH, N.; GUPTA, S.; RATHORE, V. Comparative antimicrobial study of ethanolic extract of leaf and rhizome of Curcuma longa Linn. Pharmacog J., v.9, p.208-212, 2017.

SODAMOLA, M.O.; JIMOH, W.A.; ADEJOLA, Y.A. et al. Effect of turmeric (Curcuma longa) root powder (TRP) on the growth performance, hematology and serum biochemistry of African catfish (Clarias gariepinus). Acad. J. Agric. Res., v.4, p.593-597, 2016.

SONG, L.; GUO, Z.; WANG, A. Effects of Isatis root polysaccharide on non-specific immune responses and nutritive indices in obscure pufferfish, Takifugu obscurus. Aquacult. Res., v.49, p.603-613, 2018.

STANDARD methods for the examination of water and wastewater. 21.ed. Washington, DC.: APHA, 2005.

TAVARES-DIAS, M.; ISHIKAWA, M.M.; MARTINS, M.L. et al. Hematologia: ferramenta para o monitoramento de estado de saúde de peixes em cultivo. Tópicos especiais em saúde e criação animal. São Carlos: Pedro \& João Editores, 2009.
TESKE, M.; TRENTINI, A.M. Compêndio de fitoterapia herbarium. 3.ed. São Paulo: Herbarium, 1997. 317p.

THRALL, D. Diagnóstico de radiologia veterinária. Rio de Janeiro: Elsevier, 2014. $1894 \mathrm{p}$.

VALENTIM, D.S.S.; DUARTE, J.L.; OLIVEIRA, A.E.M.F.M. et al. Effects of a nanoemulsion with Copaifera officinalis oleoresin against monogenean parasites of Colossoma macropomum: a neotropical serrasalmidae. J. Fish Dis., v.41, p.1041-1048, 2018.

VENSKUTONIS, P.R. Effect of drying on the volatile constituents of thyme (Thymus vulgaris L.) and sage (Salvia officinalis L.)." Food Chem., v.59, p.219-227, 1997.

VICENTE I.S.; ELIAS F.; FONSECA-ALVES, C.E. Perspectivas da produção de tilápia do Nilo (Oreochromis niloticus) no Brasil. Rev. Ciênc. Agrar., v.37, p.392-398, 2014.

YUSUF, M.; HASSAN, M.A.; TAG, H.M. et al. Influence of turmeric (Curcuma longa) on performance, histomorphology and microbiota of intestine in juvenile tilapia (Oreochromis niloticus). Int. J. Agric. Sci. Vet. Med., v.5, p.7-16, 2017.

ZACHARY, J.F.; MCGAVIN, D.; MCGAVIN, M.D. Bases da patologia em veterinária. Rio de Janeiro: Elsevier Brasil, 2018. 1408.

ZAR, J.H. Biostatistical analysis: multiple comparisons. 5.ed. New Jersey: Upper Saddle River, 2010. Chap.11, p.227-232. 